\section{Genome patenting concerns intensify}

US President Bill Clinton and British Prime Minister Tony Blair are interested in ensuring that scientists have free access to the data emerging from human genome research. But they are not about to sign a formal trade agreement that would, in effect, bar private companies from snapping up genome-related patents, as suggested in a 20 September report in the Londonbased Guardian newspaper. The White House flatly denied the suggestion when contacted by Nature Medicine.

The newspaper picked up on talks between Clinton and Blair about their possible endorsement of an existing policy, called the Bermuda Accord, which calls on human genome researchers to post their findings on public databases every 24 hours, says Rachel Levinson, Assistant Director for Life Sciences at the White House Office of Science and Technology Policy. That way, everyone will have an equal crack at the data. "It's something that the governments agree on already," Levinson says. "[The talks focused on] whether we should do something at a higher level that would show we endorse it."

Levinson said the White House is not opposed to genome-related patents, per se. Instead, Clinton and Blair will urge privately funded scientists to live by the same daily posting rule that applies to researchers funded by the US government's Human Genome Project and the United Kingdom's Wellcome Trust and supported by scientists from France, Germany and Japan.

The Guardian story also stated that British Science Minister Lord Sainsbury "pressed the US government to scrap an agreement with...Craig Venter...to patent as many human genes as possible." Venter's company, Celera Genomics, shook up the field last year when he announced that he had found a way to cut years off the laborious sequencing effort and beat government-funded efforts. Even though the Human Genome Project hopes to release a "working draft" of the genome next spring, some researchers and consumer groups worry that Venter will complete the work first and sell his findings to pharmaceutical companies. If that happens, it is possible that the companies could try to patent relevant sections of the genome, thus limiting its availability to other scientists. Levinson says that the story is "untrue...with respect to any deal to prevent entrepreneurs from getting patents." And Celera spokesperson Paul Gilman says there were no negotiations between Blair and Clinton regarding Celera. Gilman also points out that the company has no intention of limiting access to its data, but it will post selected sequences quarterly rather than daily.

\section{In other patent news...}

The US government's system of tracking its own patents is ineffective, according to a new report from the General Accounting Office. Government-funded researchers who patent new products are not completing the paperwork that lets the federal government know that a product exists. Although they usually mention the government's interest on the patent form, the researchers often fail to file a "confirmatory license" with Patent and Trademark Office. That separate statement allows the federal government keep track of patents. The concern is that it could miss out on revenue from inventions from research that it has funded.

Out of 633 patents submitted by joint National Institutes of Health and university collaborations, only 490 were reported to the agency's separate electronic database. Moreover, the unnamed universities dispute the government's claim to about half of the missing patents.

$$
\text { Tinker ReAdy, Boston }
$$

\title{
Canadian fight over thalassemia drug worsens
}

Although it hardly seemed possible when Nature Medicine reported the story last year (Nature Med. 4, 1095; 1999) the battle between Nancy Olivieri, a senior scientist at the Hospital for Sick Children, Toronto, and the Canadian pharmaceutical company Apotex, has intensified. The reason-the drug at the center of the fight, Deferiprone, was approved in Europe this August and is now headed for Olivieri's backyard, Canada.

Deferiprone is a drug for the treatment of the blood disorder thalassemia. Thalassemia patients require transfusions every 2-4 weeks, which cause an accumulation of iron in the body. Unless they are treated with an iron chelator, they develop iron-induced toxicity and die, typically in their late 20s. The only chelating drug now available, Desferal, must be given by infusion-injection five nights a week for 8-12 hours. Thus, Deferiprone, has the considerable advantage that it can be given orally.

However, in 1997, Olivieri published findings that the drug causes severe liver toxicity and is ineffective. She is supported in this belief, which has now turned into a campaign, by David Nathan, president of the Dana-Farber Cancer Institute, and Sir David Weatherall, Regious Professor of Medicine at the University of Oxfordboth experts on thalassemia. "The leading thalassemia experts in the United States have cautioned on the use of the drug," says Nathan.

But according to Eli Betito, director of public affairs at Apotex, Olivieri's claims have "no scientific basis." Betito told
Nature Medicine that "one hundred and fifty physicians are using the drug in Italy with no evidence of toxicity." And Apotex' vice president, Michael Spino, counters that both Nathan and Weatherall are personal friends of Olivieri and have no experience with Deferiprone. "Weatherall and I probably have more experience of thalassemia treatment with iron chelators than anyone in the world," replies Nathan. "I have used [Deferiprone] only once and it was incredibly toxic."

In short, Apotex accuse Olivieri of turning the national media against the company to rally support for her cause. "She is trying to glorify her own image [with this]," says Betito. Meanwhile, Olivieri supporter and a senior investigator at the hospital, John Dick, says that Apotex has run a campaign geared at damaging Olivieri's reputation as a scientist from the start.

The drug is now being evaluated with regulatory body Health Canada, and Apotex is hoping for a decision on approval within the next three months.

LaURa BonetTa, Washington D.C.

Nature Medicine feedback... Questions, comments, complaints? We welcome feedback on the news presented here in the print issue of Nature Medicine and in the "Breaking News" feature on our website (http://medicine. nature.com) Please send your comments on the news (or any other aspect of Nature Medicine) to the Associate Editor, News at k.birmingham@nature.com. 